\title{
Bioturbation as Driver of Zooplankton Recruitment, Biodiversity and Community Composition in Aquatic Ecosystems
}

\author{
Mikael Gyllström, Thomas Lakowitz, Christer Brönmark, \\ and Lars-Anders Hansson*
}

Department of Ecology/Limnology, Lund University, Ecology Building, 22362 Lund, Sweden

\begin{abstract}
In an experimental study we assessed if benthic bioturbating invertebrates affect the recruitment (hatching) of zooplankton from the sediment, and if this effect persists as differences in the zooplankton community in the water column, that is, if bioturbation quantitatively stimulates benthicpelagic coupling. We investigated the effects of four different benthic invertebrates (Asellus aquaticus, Chironomus plumosus, Tubifex tubifex in the presence or absence of the predator Sialis lutaria). In total, 45 zooplankton taxa hatched from the sediment and the hatching success of some of these was dependent on the species identity of the bioturbating invertebrate. The predator Sialis reduced the abundance of all three invertebrate species, but tended to positively influence the zooplankton recruitment rates, possibly through increasing the activity of the bioturbating invertebrates. The most striking effect of bioturbation on the hatching and
\end{abstract}

pelagic zooplankton community properties was that, on average, $11 \%$ more species hatched in the Asellus treatment than in any other treatment. This was also mirrored in the zooplankton water column community where, on average, $7 \%$ more species established a viable population in treatments with Asellus as bioturbator. In a complementary field survey, Asellus was more common in littoral than in profundal sediments. Because Asellus strongly affected recruitment of zooplankton in our experiment, we argue that bioturbation may partly explain why recruitment of resting stages of both phyto- and zooplankton is generally higher in littoral than in profundal areas.

Key words: benthic-pelagic coupling; life-history; habitat shifts; recruitment; zooplankton; eggbank; bioturbation; biodiversity.

\section{INTRODUCTION}

Studies in aquatic ecosystems tend to focus on either benthic or pelagic processes, even though a number of important processes link these habitats, implying that benthic-pelagic coupling is not fully

Received 27 November 2007; accepted 23 July 2008; published online 16 September 2008

*Corresponding author; e-mail: lars-anders.hansson@limnol.lu.se recognized (Vadebonceur and others 2002; Vander Zanden and others 2005). Benthic-pelagic coupling is a broad concept encompassing a number of processes, such as redistribution of sediment particles by benthic organisms ("bioturbation"), and nutrient exchange between sediment and water (Petr 1977; Svensson 1998; Meysman and others 2006). Moreover, fish feeding on benthic prey may subsidize an increased top-down pressure on their 
pelagic prey (Jeppesen and others 2003), suggesting that the planktons are indirectly affected by benthic-pelagic coupling. Pelagic plankton communities are also directly affected by benthic processes because virtually all pelagic phyto- and zooplankton have benthic dormant stages (Fryxell 1983; Gyllström and Hansson 2004). Zooplankton diapausing eggs may persist in lake sediments more than 300 years (Hairston and others 1995), and such egg-banks in the sediment may influence the population ecology and evolution of zooplankton (Hairston 1996; Gyllström and Hansson 2004). Zooplankton diapausing eggs typically need an environmental cue to hatch, the most common being light (photoperiod) and temperature, or a specific combination of these two (Gyllström and Hansson 2004). If eggs through any process such as sedimentation or active transport by benthic organisms are brought below the surface layer, they will not be able to hatch. Bioturbation may move eggs either up toward the surface or downward, depending on the behavior of the benthic organism turbating the sediment (Marcus and Schmidt-Gengenbach 1986; Kearns and others 1996). Bioturbation of the sediment by Asellus aquaticus and Chironomus plumosus significantly increased recruitment of cyanobacteria and zooplankton, affecting the development of their planktonic populations (Ståhl-Delbanco and Hansson 2002), and mechanical mixing increased hatching of copepods (Hairston and Kearns 2002). In the latter study the hatching rate of the calanoid copepod Diaptomus sanguineus increased with the depth of the mixed sediment layer, implying that the effect of a bioturbating species may depend on the magnitude of its sediment-mixing activities. Some benthic invertebrates, such as amphipods, may also prey upon diapausing eggs (Cáceres and Hairston 1998), and predation by marine amphipod and bivalve predators on diapausing eggs lead to decreased zooplankton hatching in an experimental setup (Viitasalo and others 2007). But to our knowledge no one has studied how interactions among benthic species affect bioturbation and hatching of diapausing eggs.

Benthic processes are thus potentially important for the ecology and evolution of zooplankton, but knowledge of these processes is indeed limited. Hence, it may be of considerable importance to evaluate effects of benthic communities on hatching from diapausing eggs and resulting indirect effects on the pelagic plankton community. If bioturbation affects zooplankton recruitment from diapausing eggs, processes controlling abundance and behavior of bioturbating organisms may indi- rectly affect zooplankton communities. We therefore hypothesize that predation on benthic bioturbators may affect zooplankton recruitment from the sediment. The effect of predation on zooplankton hatching through decreased biomass or abundance of a bioturbating species should, however, depend on whether the bioturbation of that particular species increases or decreases zooplankton hatching rates (that is, if it buries diapausing eggs deeper into the sediment or brings them toward the surface). The effect of hatching from diapausing eggs on the active zooplankton community varies seasonally and among species, depending on factors in the pelagic environment, such as food quantity and quality, or the relation between hatching rate and the size of the pelagic population (Arbaciauskas and Gasiunaite 1996; Gyllström 2004). We therefore expect the effect of bioturbation and predation on bioturbating species in the benthic habitat to interact with pelagic processes in shaping the zooplankton community.

To quantify effects of bioturbation on pelagic zooplankton communities we performed a laboratory study in aquaria using natural lake sediments. We used four benthic invertebrate species common in lake sediments but with potentially different effects on the redistribution of lake sediments: the aquatic sowbug (Asellus aquaticus), an omnivore that redistributes the top layer of the sediments while rummaging for food, a midge larvae (Chironomus plumosus), which makes U-shaped burrows in the sediment, and the tubificid oligochaete Tubifex tubifex, which burrows head down into the sediment feeding on organic material from deeper layers and depositing its feces at the sediment surface. The predatory alderfly larvae Sialis lutaria also forages in the sediment and may thus have a bioturbating effect in itself, and may also alter the behavior of its benthic prey, but we hypothesize that the main effect is through consumption of their prey species, reducing the bioturbation of these. Compared to C. plumosus and T. tubifex, A. aquaticus is more active and moves around while foraging, which implies that it should redistribute larger volumes of sediment and that its bioturbation is more evenly spread "horizontally" in the sediment.

We hypothesize that the bioturbating behavior of benthic invertebrates affects the number of species and abundance of zooplankton hatching from diapausing eggs. We predict that the highest hatching rates would be found in the Asellus treatment due to their higher activity in the sediment. We also expect the effect of C. plumosus to be larger than that of T. tubifex. The latter species is smaller and 
feeds selectively on particles much smaller than zooplankton resting eggs which means that it may actually be predicted to have a negative impact on the hatching of zooplankton by covering the eggs at the surface with organic material thereby creating a barrier through which light may not penetrate (Matisoff and others 1999; Rodriguez and others 2001). The generality of the experimental study was evaluated using a large data set on the distribution of the different bioturbators in littoral and profundal sediments, respectively.

\section{Material AND Methods}

The experiment was conducted in a walk-in incubator and consisted of a setup of 50 plastic aquaria measuring $0.32 \times 0.20 \times 0.20 \mathrm{~m}$. Light was provided by fluorescent tubes and mean light intensity reaching the water surface of the aquaria was 11.0 $( \pm 3.5) \mu \mathrm{mol} \mathrm{m}{ }^{-2} \mathrm{~s}^{-1}$. Three species of bioturbating invertebrates (Asellus aquaticus, Tubifex $s p$. and, Chironomus plumosus) and one invertebrate predator, Sialis lutaria were used in the experiment. Asellus and Sialis were collected from the nearby Lake Krankesjön and Chironomus from Lake Krankesjön and Lake Sövdesjön, both located in southernmost Sweden $\left(55^{\circ} \mathrm{N}, 13^{\circ} \mathrm{E}\right)$. A commercial fish-food dealer supplied Tubifex.

Surface sediment (0-0.1 m sediment depth) was collected from $4 \mathrm{~m}$ water depth in Lake Dagstorpssjön, $\left(55^{\circ} 52^{\prime} \mathrm{N}, 13^{\circ} 32^{\prime} \mathrm{S}\right)$ in southern Sweden. The sediment was sieved through $1 \mathrm{~mm}$ mesh to obtain a homogenous sediment free of larger animals and added to the plastic aquaria to a depth of $0.05 \mathrm{~m}$. The water content of the sediment in Lake Dagstorpssjön is $900 \mathrm{mg} \mathrm{g}^{-1}$ wet weight and the organic content is $310 \mathrm{mg} \mathrm{g}^{-1}$ dry weight. Sediment was allowed to settle for 13 days in complete darkness and $6^{\circ} \mathrm{C}$ to prevent any recruitment from diapausing phyto- or zooplankton. The aquaria were then carefully filled up with tap water to a final volume of 12 l. Because tap water in Sweden is only very lightly chlorinated, it contains no detectable amounts of chlorine or chloramines at the end user (Local Water Authority; pers. comm). At the start of the experiment (2 May 2006), the temperature was raised to $14^{\circ} \mathrm{C}$ and a light:dark cycle of 15:9 was used throughout the experiment, which ended 6 weeks later (14 June).

The experiment followed a $4 \times 2$ factorial design with four levels of bioturbation, two levels of predation and five replicates of each treatment, all randomly placed in the walk-in incubator. The four bioturbation treatments consisted of one control with no animals and three single species treatments with 60 chironomids, 60 Asellus, and 120 Tubifex, respectively. The two predation treatments were no Sialis (control) or five Sialis per aquarium. A higher abundance of Tubifex was used to compensate for their lower individual biomass. We first added Chironomids, Asellus, and Tubifex and allowed them to settle in the sediment before adding the predator Sialis in the predator-prey treatments. Low oxygen levels during the initial week led to mortality in all treatments. We therefore took measures to compensate for dead animals in the sediment, and added an extra $10 \%$ new animals in all treatments and an additional two predators after the first week. To avoid further oxygen depletion the aquaria were aerated during the remainder of the experiment. Throughout the experiment visible dead animals were removed and replaced with new ones. Moreover, hatched chironomid larvae, indicated by empty shells at the water surface, were immediately replaced. Water loss due to sampling and evaporation was compensated for by addition of water up to the original level. At the end of the experiment, the sediment from each aquarium was sieved through $1 \mathrm{~mm}$ mesh. All live animals remaining were stored in $96 \%$ ethanol and later counted and measured.

Once every week throughout the experiment, starting on the first day of the experiment, the aquaria were sampled for zooplankton recruitment from diapausing eggs. Recruitment from diapausing eggs in the sediment was measured in the aquaria with inverted funnel traps, one in each aquarium, covering $8.7 \times 10^{-3} \mathrm{~m}^{2}$, corresponding to about $14 \%$ of the sediment surface. The traps were a modification of the type used by Hansson and others (1994), which consist of a transparent plastic inverted funnel (105 mm diameter) leading into a $30 \mathrm{ml}$ glass vial. A window in the funnel covered with a plankton net (mesh size $50 \mu \mathrm{m}$ ) allowed exchange of water and oxygen, but excluded animals from the surrounding water column. Initially, the traps were filled with tap water, lowered and then gently pushed $10 \mathrm{~mm}$ into the sediment. To avoid contamination by zooplankton a sieve (mesh size $50 \mu \mathrm{m}$ ) was held under the traps as they were lowered through the water column. The traps were left for approximately $48 \mathrm{~h}$ before they were retrieved. At the end of each sampling period the contents of the glass vial were preserved with Lugol's solution and the entire sample was later examined under an inverted microscope at $100 \times$ magnification. Hatching rate was calculated as the number of individuals emerging $\mathrm{d}^{-1} \mathrm{~m}^{-2}$. The abundance and community composition of zooplankton in the water column at the two last 
sampling dates (presented as the average of the two sampling dates) was used to estimate the resulting pelagic zooplankton community. An integrated sample of the water column from the surface to the bottom was taken in the water column of the aquaria. Three such samples obtained with a tube sampler (26 mm diameter) were pooled and filtered through a plankton net (mesh size $50 \mu \mathrm{m}$ ). Animals retained on the net were preserved in Lugol's solution and the zooplankton community was examined in the same way as the zooplankton from the traps and abundance calculated as number of individuals $\mathrm{l}^{-1}$. Zooplanktons were determined to species level, except for copepods, which were divided into cyclopoids and calanoids. Further, due to the distortion of species of the genus Synchaeta in Lugol's solution, identification was only possible to genus level.

Effects of predation and bioturbating species on cumulative hatching (total abundance and total number of species found in each aquarium during the course of the experiment) of zooplankton from diapausing eggs in the sediment, and zooplankton abundance and species richness in the water column were analyzed with two-way ANOVA, with Tukey post-hoc tests. All variables were checked for homogeneity of variance and normal distribution of residuals and, if necessary, transformed before analysis. To further examine the effect of hatching from diapausing eggs on the resulting zooplankton community correlations of water column abundance and diversity and cumulative hatching (abundance and diversity) were performed.

To evaluate the effect of predation and bioturbating species on zooplankton community composition a PCA was performed on the water column zooplankton data and the cumulative hatching data. An unrotated factor solution was used and the resulting scores were analyzed with two-way ANOVA as described above, using predation and bioturbating species as independent variables.

To assess the implications of the results from the experiment for natural systems the spatial distribution of the involved species in lakes was investigated. Data for bioturbator species distribution in littoral and profundal sediments, respectively, were downloaded from the website of the Swedish national data host (Swedish University of Agricultural Sciences, 2007) and were collected within the Swedish national environmental monitoring programs performed by The Swedish Environmental Protection Agency (SEPA). In the national monitoring programs invertebrate profundal samples are collected in accordance with Swedish standard (SS 028190), in which five replicate samples are taken with an Ekman dredge from an area with a $100 \mathrm{~m}$ radius from over the deepest part of the lake. Animals retained on a $0.5 \mathrm{~mm}$ sieve are identified and counted. Littoral samples are collected according to European standard (SS-EN 27 828) with a hand-net (mesh-size $0.5 \mathrm{~mm}$ ) in five replicates within a $10-\mathrm{m}$ stretch along an exposed shore without vegetation. Samples are collected at a maximum depth of $1 \mathrm{~m}$ and each sample contains animals from an area of approximately $0.25 \mathrm{~m}^{2}$. Data on benthic invertebrates from 42 lakes, sampled at least once a year during 2-22 years, were used (median number of sampled years was 11). Total nitrogen and phosphorous were sampled according to methods found in SEPA report 3108 (Röndell and Zetterberg 1986) and analyzed according to Swedish standard (SS 028131 and SS 028127, respectively). Differences between littoral and profundal abundances of the investigated species were examined with paired $t$-tests.

\section{Results}

Predation by Sialis lutaria reduced the abundance of all three benthic invertebrate species (Figure 1, Table 1). In the predator-free treatments the species specific survival, expressed as a percentage of the number of individuals added at the beginning of the experiment (including the 10\% added after the first week) was higher for Tubifex $(69 \pm 15 \%$, number \pm 1 SD) than for Asellus $(44 \pm 13 \%)$ and Chironomus $(41 \pm 8 \%$ ) (one-way ANOVA with Tukey's post-hoc test on arcsine square root transformed data, SS $=0.269, F=7.443, P=0.008, \mathrm{df}=2$ ). Tubifex had the highest abundance at the end of the experiment, but Chironomus had the highest biomass (Figure 1). The number of predators surviving did not differ among treatments, whereas predator biomass differed depending on prey taxa (Table 1).

\section{Hatching Zooplankton Community Structure}

A total of 45 zooplankton taxa were found in the hatching traps: 40 rotifer species, cyclopoid, and calanoid copepods; two cladoceran species; and one ostracod species. Thirteen of these taxa were found in all treatments, but nine taxa were exclusively found in one treatment. Three taxa were found only in the Chironomus treatment, five only in the Asellus treatment, and one taxon was exclusive to the Tubifex treatment. The most common taxa were in decreasing order Synchaeta spp, Filinia longiseta, and Trichocerca cylindrica, which were among the five most abundant species in all treatments. Two 

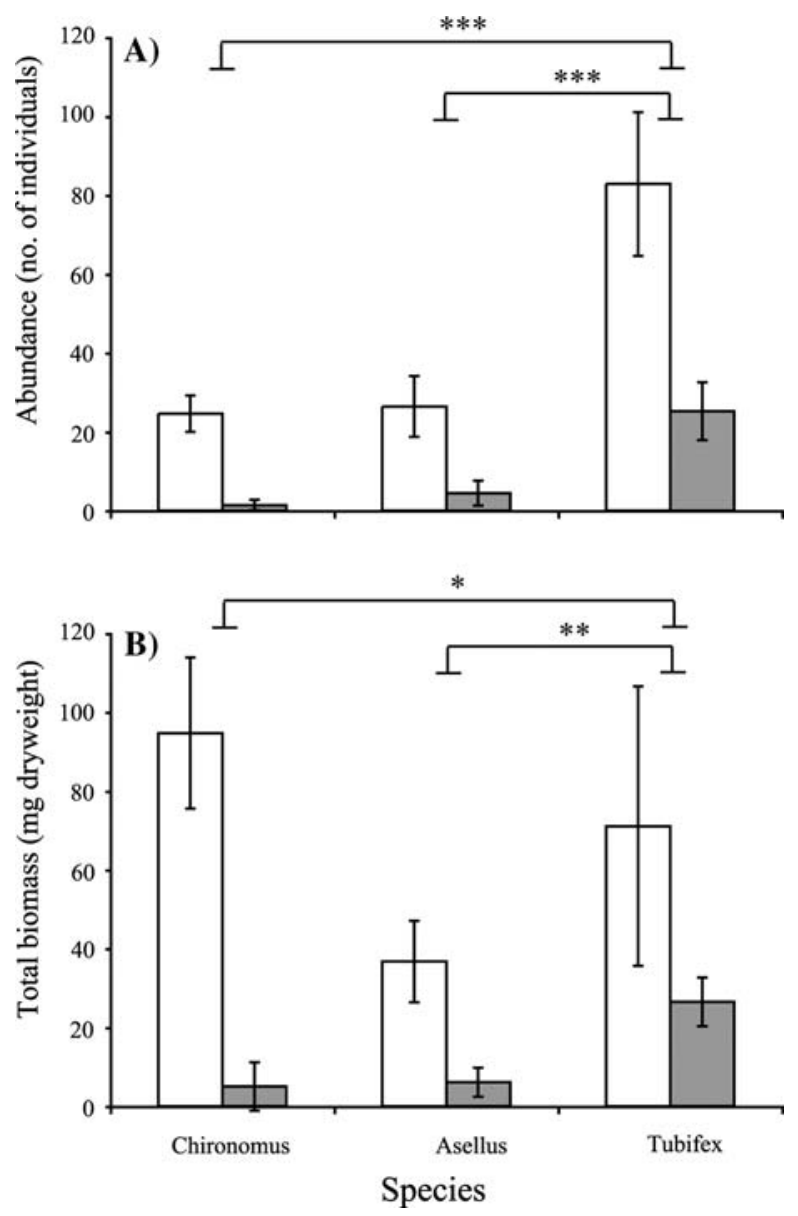

Figure 1. The effect of predation on bioturbating species abundance and biomass. (A) abundance (number of individuals) and (B) biomass (mg dry weight) of Chironomus, Asellus, and Tubifex in treatments with and without predator. White bars denote treatments without and gray bars with predators. Error bars indicate one standard deviation.

of the five species with the highest cumulative hatching in the Asellus treatment were very rare (less than $0.5 \%$ of the cumulative hatching) in the other treatments. Abundance of hatching zooplankters did not differ from the control for any of the treatments (Table 2), but the Asellus treatment had significantly higher cumulative hatching than the Chironomus treatment (Figure 2). The highest species richness of hatching zooplankton was found in the Asellus treatment (Figure 2). Abundances of hatching zooplankton always tended to be higher in treatments with, than without predators (Figure 2, Table 2). The PCA analysis of the cumulative hatching data generated 15 components with an Eigenvalue above 1. The most pronounced drop in the amount of variance explained by each component was after the first three components, which explained $30 \%$ of the variance in the material. The scores of these three components were used as dependent variables in two-way ANOVA analyses with bioturbating species and predation as independent variables. The Asellus treatment had significantly higher scores than all other treatments for the first two components. The first component, which explained $11 \%$ of the variation, was positively correlated with the abundance of Ascomorpha sp., Asplanchna priodonta, Brachionus angularis, Cephalodella gibba, Filinia longiseta, Polyarthra remata, Trichocerca capucina, Trichocerca cylindrica, Trichotria teractis, and Euchlanis sp. (Figure 3A). The second component, which explained $10 \%$ of the variation, was positively related to the abundance of Argonotholca foliacea, Ascomorpha sp., Brachionus angularis, Trichocerca porcellus, Calanoid nauplii, Bosmina longirostris and negatively correlated with Filinia longiseta and Notholca labis (Figure 3B). Predation treatments had higher scores in the third component, which explained $9 \%$ of the variation, and were positively related to the abundance of, Trichocerca porcellus, Calanoid nauplii, Bosmina longirostris and negatively related to, Ascomorpha sp., Cephalodella gibba, Lecane sp., and Polyarthra dolichoptera (Figure 3C).

\section{Water Column Zooplankton Community Structure}

At the first sampling date no planktons were found in the water column in any treatment. Hence, all zooplankton species observed at later dates originated from the sediment and the animals recorded in the water were therefore a result of hatching and subsequent population growth in the water column. At the end of the experiment 31 zooplankton taxa were found in the water column of the aquaria: 25 rotifer species, cyclopoid, and calanoid copepods; three cladoceran species; and one ostracod species. This means that not all species found in the hatching traps established a viable population in the water column and the realized species richness was lower, compared to the cumulative number of species that had hatched, in all treatments. On average $60 \%$ of the species hatching into the water column established a population. The only species found in the water column that was not detected in the hatching traps was Diaphanosoma brachyurum. None of the species that were unique to treatments in the hatching traps established a viable population in the water column. The most common species were Synchaeta sp., Filinia longiseta, Polyarthra dolichoptera, which were among the five most abundant species in all treatments, 
Table 1. Two-way ANOVA on the Effects of Two Fixed Independent Factors: Bioturbating Species Identity (Four Levels: Control, Chironomus, Asellus, and Tubifex) and Predation (Absence or Presence of Sialis)

\begin{tabular}{|c|c|c|c|c|c|}
\hline Variable & Source of variation & SS & $\mathrm{df}$ & $F$ & $P$ \\
\hline \multicolumn{6}{|c|}{ Bioturbating species } \\
\hline \multirow[t]{4}{*}{ Abundance } & Bioturbating species & 3.524 & 2 & 48.918 & $<0.001$ \\
\hline & Predation & 4.624 & 1 & 128.382 & $<0.001$ \\
\hline & Bioturb spec. $\times$ pred & 0.424 & 2 & 5.884 & $<0.01$ \\
\hline & Error & 0.864 & & & \\
\hline \multirow[t]{4}{*}{ Total biomass } & Bioturbating species & 1.125 & 2 & 7.795 & $<0.01$ \\
\hline & Predation & 5.531 & 1 & 76.686 & $<0.001$ \\
\hline & Bioturb spec. $\times$ pred & 1.390 & 2 & 9.634 & 0.001 \\
\hline & Error & 1.731 & & & \\
\hline \multicolumn{6}{|l|}{ Predator } \\
\hline \multirow[t]{2}{*}{ Abundance } & Bioturbating species & 2.800 & 3 & 0.732 & N.S. \\
\hline & Error & 20.400 & & & \\
\hline \multirow[t]{2}{*}{ Total biomass } & Bioturbating species & 2888 & 3 & 23.381 & $<0.001$ \\
\hline & Error & 659 & & & \\
\hline
\end{tabular}

Dependent variables were: abundance and biomass of Chironomus, Asellus, Tubifex at the end of the experiment. One-way ANOVA on the effect of bioturbating species on Sialis abundance, total biomass, and individual biomass. Test based on LOG ${ }^{10}$ transformed data.

Table 2. Two-way ANOVA on the Effects of Two Fixed Independent Factors: Bioturbating Species (Four Levels: Control, Chironomus, Asellus, and Tubifex) and Predation (Absence or Presence of Sialis)

\begin{tabular}{|c|c|c|c|c|c|}
\hline Variable & Source of variation & SS & df & $F$ & $P$ \\
\hline \multicolumn{6}{|l|}{ Zooplankton hatching } \\
\hline \multirow[t]{4}{*}{ Abundance } & Bioturbating species & 0.357 & 3 & 3.490 & $<0.05$ \\
\hline & Predation & 0.205 & 1 & 6.002 & $<0.05$ \\
\hline & Bioturb spec. $\times$ pred & 0.098 & 3 & 0.954 & N.S. \\
\hline & Error & 1.091 & & & \\
\hline \multirow{4}{*}{ Species richness } & Bioturbating species & 215.2 & 3 & 13.162 & $<0.001$ \\
\hline & Predation & 12.1 & 1 & 2.220 & N.S. \\
\hline & Bioturb spec. $\times$ pred & 14.7 & 3 & 0.899 & N.S. \\
\hline & Error & 201.2 & & & \\
\hline \multicolumn{6}{|c|}{ Water column zooplankton } \\
\hline \multirow[t]{4}{*}{ Abundance } & Bioturbating species & 0.982 & 3 & 3.165 & $<0.05$ \\
\hline & Predation & 0.008 & 1 & 0.077 & N.S. \\
\hline & Bioturb spec. $\times$ pred & 0.655 & 3 & 2.111 & N.S. \\
\hline & Error & 3.309 & & & \\
\hline \multirow[t]{4}{*}{ Species richness } & Bioturbating species & 71.20 & 3 & 5.519 & $<0.01$ \\
\hline & Predation & 2.500 & 1 & 0.581 & N.S. \\
\hline & Bioturb spec. $\times$ pred & 17.10 & 3 & 1.326 & N.S. \\
\hline & Error & 137.6 & & & \\
\hline
\end{tabular}

Dependent variables were cumulative total abundance of hatched zooplankton and the total abundance of zooplankton in the water column at the end of the experiment, cumulative species richness of hatched zooplankton species and in the water column. Test based on LOG ${ }^{10}$ transformed data.

and Conochilus unicornis which was among the five most abundant species in all treatments except the chironomid treatment with predators. Except for the higher abundance of zooplankton in the Asellus treatment compared to the Chironomus treatment, no other treatment effects on the water column zooplankton abundance were found (Figure 4,
Table 2). The higher species richness in the hatching traps of the Asellus treatments was also mirrored in the water column zooplankton. There was a weak but significant positive correlation between cumulative number of hatched zooplankton and abundance in the water column (Pearson correlation, $r=0.473 ; \quad P=0.002 ; n=40 ; \quad$ Figure $5 \mathrm{~A}$ ). 

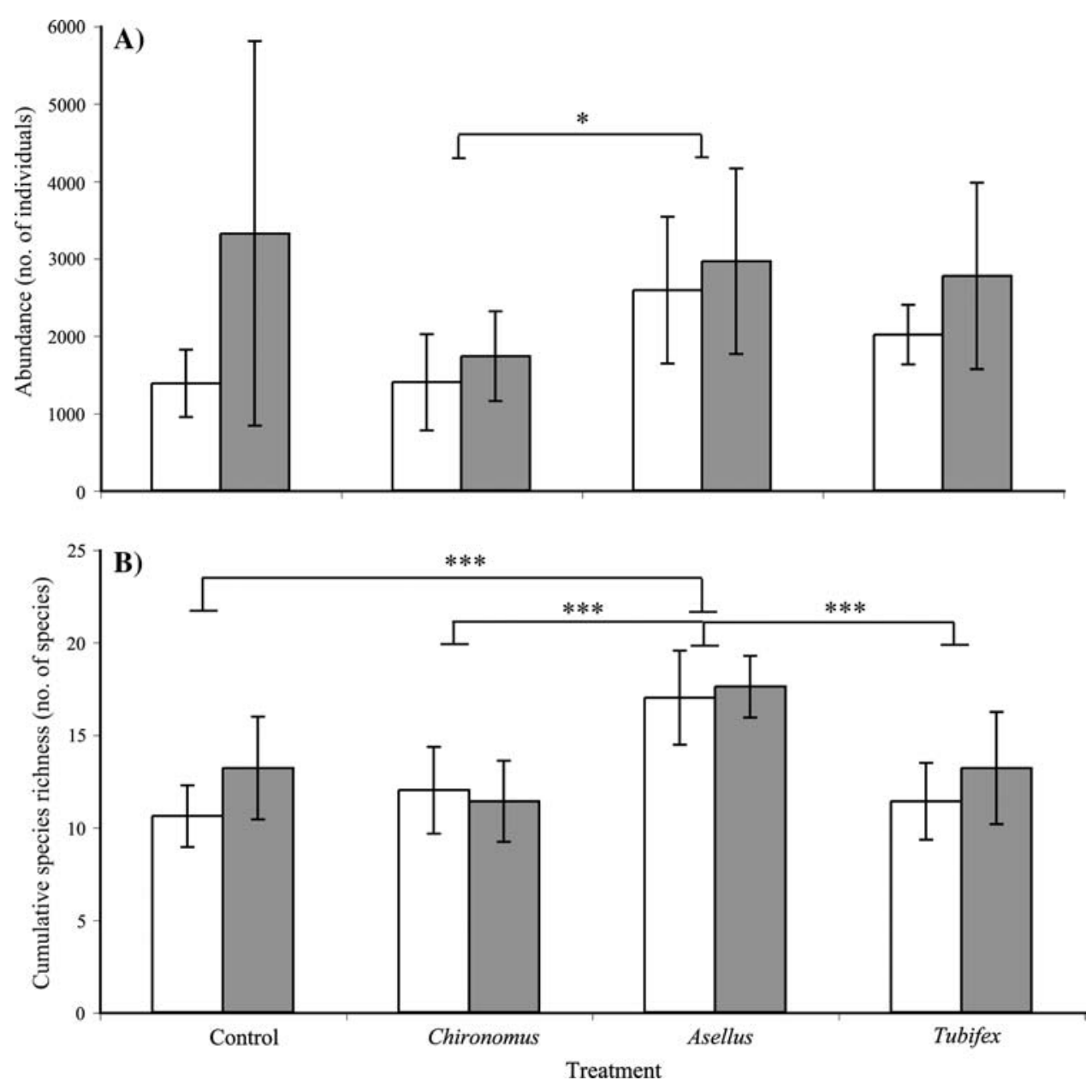

Figure 2. Treatment effects on zooplankton hatching from diapausing eggs. (A) cumulative abundance of zooplankton found in hatching traps. (B) Cumulative species richness of zooplankton found in hatching traps. White bars denote treatments without and gray bars treatments with predators. Error bars indicate one standard deviation. Asterisks denote significant differences between treatments with different bioturbating species found with Tukey's post-hoc test $\left({ }^{*} P<0.05,{ }^{* *} P<0.01\right.$, $* * * P<0.001)$.
Moreover, zooplankton species richness in the water column was positively correlated to cumulative species richness in the hatching traps (Pearson correlation, $r=0.653 ; \quad P<0.001 ; n=40$ ) (Figure 5B).

The PCA analysis of zooplankton abundance in the plankton generated 13 components with an Eigenvalue above 1 . The amount of variation explained by each component leveled off after the first six components, which explained $51 \%$ of the variance in the material. The scores of these components were used as dependent variables in twoway ANOVA analyses with bioturbating species and predation as independent variables. With respect to zooplankton in the water column, the first component, explaining $12 \%$ of the variation, was the only component with a significant relation to the treatments (Table 3). The scores of the first component were significantly higher in the Asellus treatment than the Chironomus treatment and the component was positively correlated to the abundance of Cephalodella gibba, Trichocerca cylindrica,
Trichocerca porcellus, Diaphanosoma brachyurum, and Euchlanis sp. There was also a trend of lower scores with predation in all treatments except the control (Figure 3D).

\section{Bioturbator Distribution in Natural Systems}

The 42 lakes included in the field survey range in latitude from southern to northernmost Sweden (about $\mathrm{N} 55^{\circ}-\mathrm{N} 68^{\circ}$ ) and cover a wide range in trophic status from low productivity sub-arctic lakes with phosphorus concentrations of $5 \mu \mathrm{g} \mathrm{l}^{-1}$ to eutrophic lowland lakes (Table 4). Mean surface area of the lakes is $0.9 \mathrm{~km}^{2}$ and mean depth is $6 \mathrm{~m}$ (Table 4). In the littoral zone Asellus dominated among the investigated species, whereas it showed low abundances in the profundal samples $\left(t_{33}=8.049 ; \quad P<0.001 ;\right.$ Figure 6$)$. Oligochaetae also had higher abundances in the littoral zone $\left(t_{41}=6.065 ; P<0.001\right)$. Sialis was present in both habitats but only in very low numbers in the pro- 


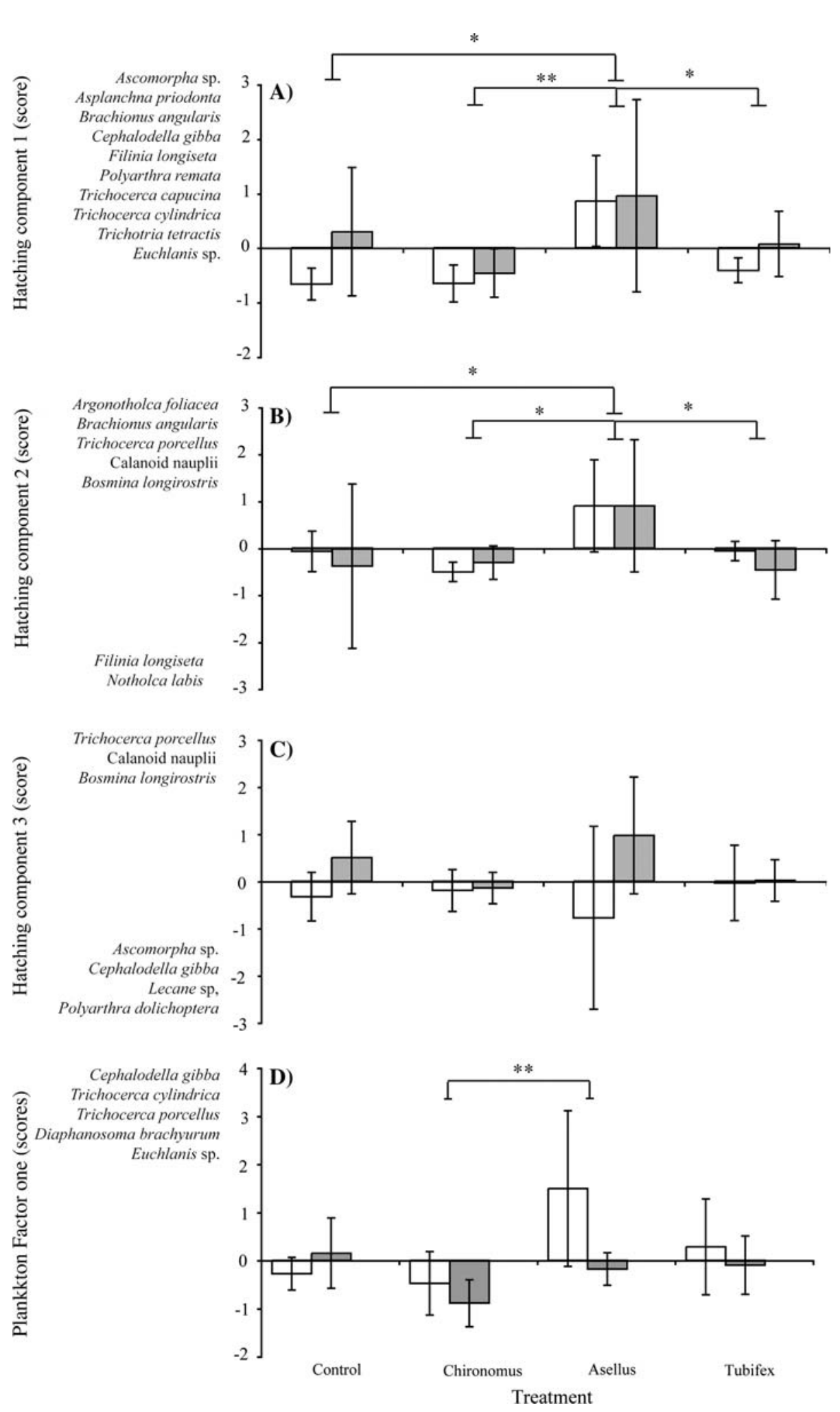

Figure 3. Treatment effects on zooplankton community composition. Panels show scores from the PCA analysis that were significantly affected by treatments. Panels $(\mathbf{A}-\mathbf{C})$ show scores from the PCA analysis of the cumulative zooplankton hatching data and panel (D) shows scores from the PCA analysis of the water column zooplankton. White bars denote treatments without and gray bars treatments with predators. Error bars indicate one standard deviation. Asterisks denote significant differences between treatments with different bioturbating species found with Tukey's post-hoc test $\left({ }^{*} P<0.05,{ }^{* *} P<0.01\right.$, $* * * P<0.001)$. Zooplankton species' names to the left of the $\mathrm{y}$-axes indicate which species were significantly correlated to that particular component. Names at the top of each axis indicate species that were positively correlated to the component and names at bottom indicate species that were negatively correlated to the component.

fundal $\quad\left(t_{34}=5.482 ; \quad P<0.001\right)$. Chironomus plumosus was the only species with slightly higher abundances in the profundal $\left(t_{22}=-2.188\right.$; $P<0.05$; Figure 6), a difference that was nonsignificant after Bonferroni correction.

\section{DiscUSSION}

Already Darwin noted that small-scale reworking activities by tiny invertebrates can have dramatic consequences at larger scales (Darwin 1881; 


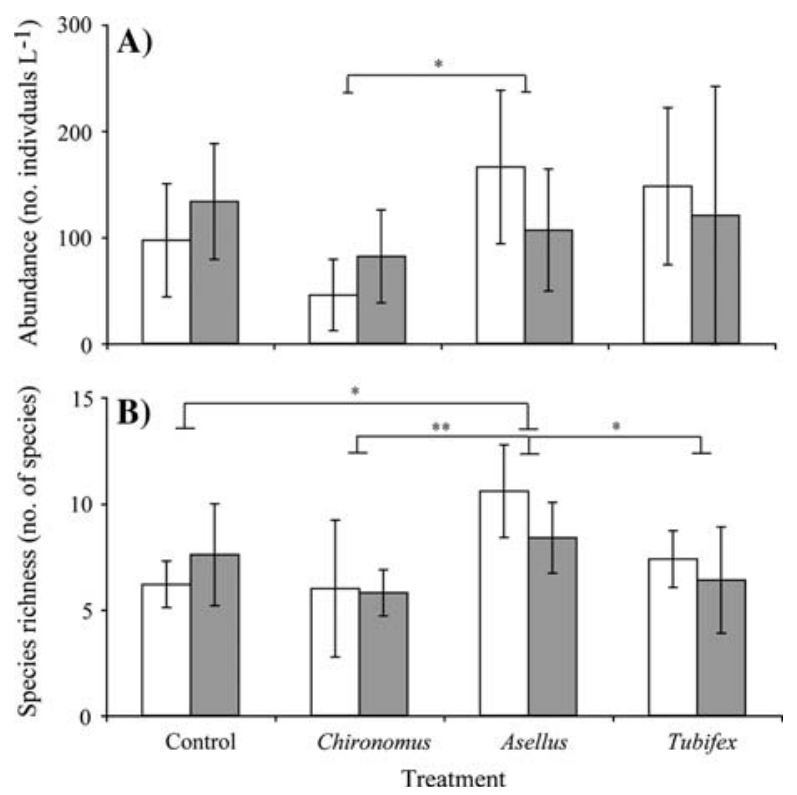

Figure 4. Treatment effects on abundance and species richness of zooplankton found in the water column in the aquaria. (A) Zooplankton abundance. (B) Zooplankton species richness. White bars denote treatments without and gray bars treatments with predators. Error bars indicate one standard deviation. Asterisks denote significant differences between treatments with different bioturbating species found with Tukey's s-hoc test $\left({ }^{*} P<0.05,{ }^{* *} P<0.01, * * * P<0.001\right)$.
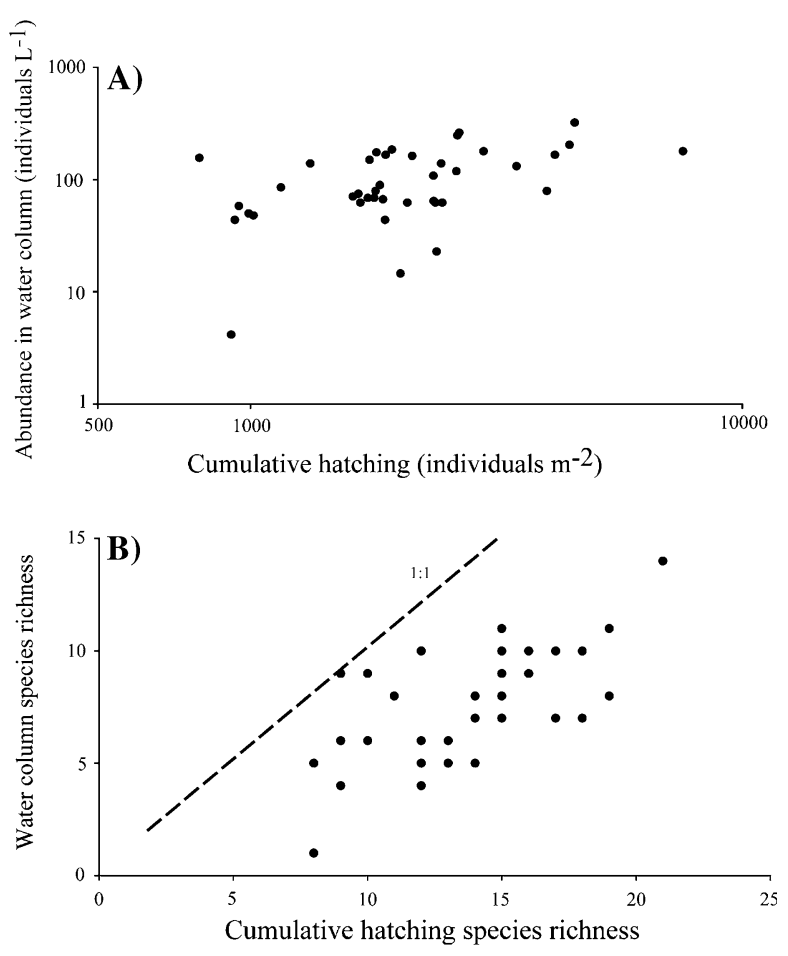

Figure 5. Correlations between hatching of zooplankton from the sediment and the abundance in the water column (upper panel) and between species richness of hatching zooplankton in relation to the species richness in the water column (lower panel). The hatched line denotes a 1:1 relation.

Table 3. Two-way ANOVA on the Effects of Two Fixed Independent Factors: Bioturbating Species (Four Levels: Control, Chironomus, Asellus, and Tubifex) and Predation (Absence or Presence of Sialis)

\begin{tabular}{|c|c|c|c|c|c|}
\hline Variable & Source of variation & SS & $\mathrm{df}$ & $F$ & $P$ \\
\hline \multicolumn{6}{|l|}{ Hatching traps } \\
\hline \multirow{4}{*}{ Component 1} & Bioturbating species & 11.98 & 3 & 5.317 & $<0.01$ \\
\hline & Predation & 1.860 & 1 & 2.477 & N.S. \\
\hline & Bioturb spec. $\times$ pred & 1.133 & 3 & 0.503 & N.S. \\
\hline & Error & 24.03 & & & \\
\hline \multirow[t]{4}{*}{ Component 2} & Bioturbating species & 11.00 & 3 & 4.308 & $<0.05$ \\
\hline & Predation & 0.169 & 1 & 0.199 & N.S. \\
\hline & Bioturb spec. $\times$ pred & 0.582 & 3 & 0.228 & N.S. \\
\hline & Error & 27.25 & & & \\
\hline \multirow[t]{4}{*}{ Component 3} & Bioturbating species & 0.458 & 3 & 0.167 & N.S. \\
\hline & Predation & 4.512 & 1 & 4.954 & $<0.05$ \\
\hline & Bioturb spec. $\times$ pred & 4.888 & 3 & 1.789 & N.S. \\
\hline & Error & 29.14 & & & \\
\hline \multicolumn{6}{|l|}{ Water column } \\
\hline \multirow[t]{4}{*}{ Component 1} & Bioturbating species & 9.106 & 3 & 4.482 & 0.01 \\
\hline & Predation & 2.582 & 1 & 3.812 & 0.06 \\
\hline & Bioturb spec. $\times$ pred & 5.640 & 3 & 2.776 & 0.057 \\
\hline & Error & 21.673 & & & \\
\hline
\end{tabular}

Dependent variables were scores from PCA analyses of the zooplankton community found in the hatching traps and in the water column 
Table 4. Ranges and Means $( \pm \mathrm{SD})$ for Total Nitrogen $\left(\mathrm{TN} ; \mu \mathrm{g} \mathrm{l}^{-1}\right)$, Total Phosphorus $\left(\mathrm{TP} ; \mu \mathrm{g} \mathrm{l}^{-1}\right)$, Surface Area $\left(\mathrm{km}^{2}\right)$, Maximum $\left(\mathrm{z}_{\max }\right)$ and Mean Depths $\left(\mathrm{z}_{\text {mean }}\right)$ among Lakes $(n=42)$ Included in the Field Survey of Macroinvertebrate Animal Distribution

\begin{tabular}{llllll}
\hline & TN & TP & Area & $z_{\text {max }}$ & $z_{\text {mean }}$ \\
\hline Range & $205-1445$ & $5-75$ & $0.04-5.0$ & $2.1-42$ & $1.5-19$ \\
Mean $( \pm 1 S D)$ & $523(276)$ & $14(13)$ & $0.9(1.1)$ & $16(10)$ & $6(4)$ \\
\hline
\end{tabular}

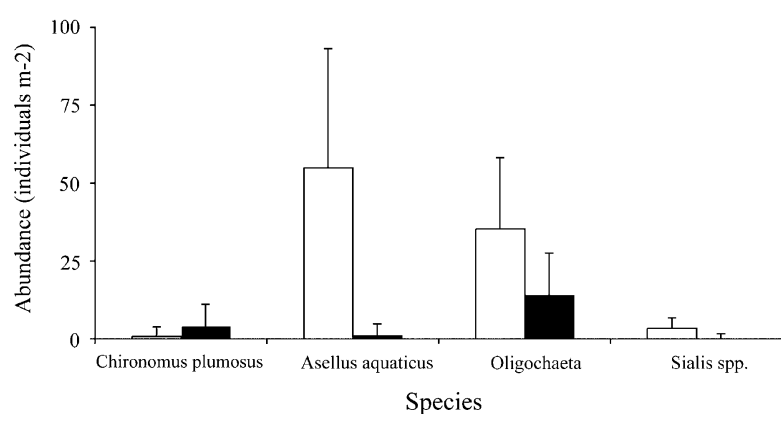

Figure 6. The abundance of Asellus aquaticus $(N=34)$, Oligocheta $(N=42)$, Chironomus plumosus $(N=33)$, and Sialis sp. $(N=35)$ in littoral (white bars) and profundal (black bars) lake sediments (means $\pm 1 \mathrm{SD})$.

Meysman and others 2006). Although Darwin's observations concerned terrestrial earthworms, his observations are indeed also valid for aquatic ecosystems where numerous taxa and size classes of animals rework the sediment. A major effect of these bioturbators is, of course, the physical redistribution of sediment particles, that is, shaping the physical features of the benthic habitat. However, these "ecological engineers" (Jones and others 1994) may not only set the stage for organisms, but also affect processes such as the oxygen demand of the sediment or the flux of minerals and nutrients between sediment and water, for example increased denitrification rates or increased precipitation of iron and phosphorus (Svensson and Leonardsson 1996; Lewandowski and others 2007) Finally, bioturbation may directly affect the rate at which species with benthic dormant stages enter the water column (Hairston and Kearns 2002; Ståhl-Delbanco and Hansson 2002).

In our study a, to our knowledge, not previously recorded effect of bioturbating species identity on species richness and community composition of hatching and water column zooplankton, was discovered. The most striking effect of bioturbation on the hatching and pelagic zooplankton community properties was that, on average, five more species (corresponding to $11 \%$ ) hatched in the Asellus treatment than in any other treatment. This effect persisted in the water column where, on average, three more species (corresponding to $7 \%$ ) were found in the Asellus treatment than in the other treatments. The species identity of the bioturbating invertebrates used in our study also had an effect on the community composition of the hatching zooplankton, an effect that was severely dampened in the water column community where the only significant difference between treatments was between Asellus and Chironomus. Most of the zooplankton species hatching from the sediment were found in several treatments, but the hatching success of some species was dependent on the species identity of the bioturbating invertebrate and this effect also persisted in the pelagic zooplankton community composition. The treatment effect on pelagic community composition was partly a result of some species occurring exclusively in a certain treatment, but partly also the effect of treatmentrelated abundance differences among species found in all treatments, for example, Filinia longiseta and Trichocerca cylindrica whose abundances were higher in the Asellus treatment (Figure 3). The species with higher abundances in the water column in the Asellus treatment were all found among the species that had a higher hatching rate in the Asellus treatment (except Diaphanosoma which was never found in any hatching trap), indicating that hatching had an influence on the community composition of the active plankton community. The significant contribution of hatching from diapausing eggs to the active community is also shown by the correlation between the cumulative number of hatched species and the species richness of the active zooplankton communities in the water column and, to a lesser extent, by the weak positive correlation between the cumulative numbers of hatching zooplankton and the abundance of zooplankton in the overlaying water (Figure 5).

In contrast to marine systems, where bioturbators tend to consume zooplankton resting stages and decrease hatching rates (Viitasalo and others 2007), our freshwater bioturbators did not decrease zooplankton hatching from the sediment to the open water, suggesting considerable differences in effects from bioturbation between marine and 
freshwater ecosystems. However, our results did not show a strong positive influence of bioturbation on zooplankton hatching rates as reported in previous studies on freshwater species (Hairston and Kearns 2002; Ståhl-Delbanco and Hansson 2002). In our study, hatching was slightly higher in the presence of a benthic invertebrate predator, which may also act as a bioturbator, but the only difference in hatching rate attributed to the other three bioturbating invertebrates was a higher hatching rate in the presence of Asellus compared to treatments with Chironomus. The lack of a significant effect between the Asellus treatment and the control was, however, due to one extreme outlier in the control treatments with Sialis, that had a cumulative hatching abundance almost three times higher (approximately 8000 individuals) than any of the other four replicates which all had relatively similar abundances (1000-3000 individuals). If this replicate was excluded from the analysis the abundance of hatched zooplankton in the Asellus treatment would have been different from the control (data not shown here).

Our study indicates that species identity of bioturbating benthic invertebrates may have an indirect effect on the water column zooplankton community through effects on species richness and identity of hatching zooplankton. The bioturbating mode of the species was, as expected, important for the recruitment to the water column. In fact, it appeared more important than the actual density of bioturbators, as indicated by the fact that although the numbers and biomass of Asellus were not higher than those of the other bioturbators it had the strongest impact on the investigated response variables. However, the hypothesized dampening effect of Tubifex or the stimulating effect of Chironomus on hatching was not observed. Also, the strongest effect of the predator was probably not the hypothesized indirect effect through consumption but rather through its bioturbation of the sediment, or possibly through an increased activity of its prey.

Biodiversity and community composition of the zooplankton community are properties that have been shown to affect important ecosystem traits such as temporal stability and energy transfer between trophic levels (Cottingham and others 2001; Steiner and others 2005; Gaedke and Kamjunke 2006). Furthermore, the intermediate position of zooplankton in lake food webs implies that a change in the diversity, or composition of the zooplankton community may have effects on both higher and lower levels in a food chain (Naeem and Li 1998; Holt and Loreau 2001; Hillebrand and
Shurin 2005). The possible importance of our results for zooplankton diversity in natural systems therefore deserves some attention.

Diversity within a habitat may be seen as being promoted by dispersal from the regional species pool and restricted by exclusion within the habitat due to biotic and abiotic factors (Hillebrand and Shurin 2005). If dispersal constrains local diversity this may have implications for ecosystem function as outlined above. In the case of zooplankton, "immigration" from the diapausing egg bank is considered to be of greater importance than dispersal between lakes due to the presence of a large egg-bank coupled with passive, slow, dispersal and rapid local adaptation that may reduce gene flow between lakes (Boileau and others 1992; De Meester and others 2002). This is nicely illustrated by the study of Loch Leven where the species richness in the egg-bank was comparable to the cumulative species richness in water samples over a 6-year period, but on any given sampling date the diversity in the water column was always lower than that of the egg-bank (May 1986). The relevance of our results for diversity in natural systems depends on the applicability of our short and small labexperiment to a natural scale, but also on the importance of bioturbation compared to a number of other processes that may vary temporally as well as spatially, within and between lakes.

The importance of hatching from the egg-bank on the water-column community is probably exaggerated by our experimental design, because of the fact that the water column was empty at the beginning of the experiment. In temperate lakes the size and diversity of the active zooplankton community varies over the year, typically low during winter but replenished by hatching from the egg-bank during spring (De Stasio 1990; Gyllström 2004; Gyllström and Hansson 2004). The hatching of zooplankton from diapausing eggs may therefore be of importance for the pelagic community, at least during the beginning of the growing season, depending on the amount of hatching zooplankton relative to the size of overwintering populations (Gyllström and Hansson 2004). The only available information known to us regarding factors governing the size of the overwintering populations is on members of the genus Daphnia, for which it was found that the occurrence of overwintering populations increase with lake depth (De Senerpont Domis and others 2007).

With respect to the importance of bioturbation by benthic invertebrates within lakes, we found that in a broad spectrum of lake types, sizes, and climatic regions including 42 lakes, Asellus was 
dominant in littoral areas. Oligochaetae (such as Tubifex sp.) were common in both habitats but more so in the littoral. Sialis occurred in lower numbers and was also most common in the littoral habitat. Chironomus on the other hand showed a more even distribution with a tendency to be more common in profundal areas (Figure 6). In our experimental study the recruitment of zooplankton from resting stages in the sediment was strongly stimulated by the activity of Asellus, whereas the other invertebrates, except for Sialis, had no effect on recruitment rates. Hence, it may be suggested that bioturbation will stimulate recruitment of zooplankton more in littoral than in profundal areas. In accordance with this notion, several studies have shown that recruitment of both phytoplankton and zooplankton is, indeed, higher in littoral than in profundal areas (Forsell and Petterson 1995; Hansson 1996; Ståhl-Delbanco and Hansson 2002; Gyllström and Hansson 2004). Although we are fully aware that the connection between our laboratory data and the field study is purely correlational, and may therefore not allow for mechanistic conclusions, this suggests that bioturbation by efficient, littoral invertebrates may partly explain why the recruitment rate from littoral sediments is generally higher than from profundal sediments. However, the quantitative importance of bioturbation compared to other features of the littoral zone, such as higher temperature, different sediment structure, more light (Hansson 1993, 2000; Rengefors and others 1998, 2004), as well as bioturbation from benthivorous fish, has to be further investigated.

If hatching is higher in the littoral zone, the relative size of the littoral zone may determine the importance of the processes suggested by our results between lakes. Lake depth is probably the most important factor influencing the relative importance of the littoral, but lake size, productivity, and water clarity also play an important role (Scheffer and others 1993). Shallower lakes are, however, also more sensitive to windinduced resuspension of the sediments, a process that also may play an important role for the observed within-lake differences in hatching of zooplankton.

In conclusion our study suggests a previously not reported benthic-pelagic coupling in aquatic systems. The species identity of bioturbating benthic invertebrates in our study affected species richness and community composition of hatching zooplankton and to a lesser, but still significant, extent the biodiversity and community composition of zooplankton in the water column. Although the relevance of these findings for natural ecosystems is unknown, our results suggest that the size of the littoral zone, inhabited by a large number of efficient bioturbators, such as Asellus, may influence the zooplankton community composition considerably by affecting hatching from dormant stages.

\section{ACKNOWLEDGEMENTS}

The study was financed by grants from Swedish Research Council (VR) and the Swedish Research Council for Environment, Agricultural Sciences and Spatial Planning (FORMAS).

\section{OPEN ACCESS}

This article is distributed under the terms of the Creative Commons Attribution Noncommercial License which permits any noncommercial use, distribution, and reproduction in any medium, provided the original author(s) and source are credited.

\section{REFERENCES}

Arbaciauskas K, Gasiunaite ZR. 1996. Growth and fecundity of Daphnia after diapause and their impact on the development of a population. Hydrobiologia 320:209-22.

Boileau MG, Hebert PDN, Schwartz SS. 1992. Non-equilibrium gene frequency divergence: persistent founder effects in natural populations. J evol Biol 5:25-39.

Cáceres CE, Hairston NG Jr. 1998. Benthic-pelagic coupling in planktonic crustaceans: the role of the benthos. Ergeb Limnol 52:163-74

Cottingham KL, Brown BL, Lennon JT. 2001. Biodiversity may regulate the temporal variability of ecological systems. Ecol Lett 4:72-85.

Darwin C. 1881. The formation of vegetable mould through the action of worms with observation of their habits. John Murray.

De Meester L, Gomez A, Okamura B, Schwenk K. 2002. The monopolization hypothesis and the dispersal-gene flow paradox in aquatic organisms. Acta Oecol 23:121-35.

De Senerpont Domis LN, Mooij WM, Hülsmann S, van Nes EH, Scheffer M. 2007. Can overwintering versus diapausing strategy in Daphnia determine match-mismatch events in zooplankton-algae interactions. Oecologia 150:682-98.

De Stasio BT Jr. 1990. The role of dormancy and emergence patterns in the dynamics of a freshwater zooplankton community. Limnol Oceanogr 35:1079-90.

Forsell L, Petterson K. 1995. On the seasonal migration of the cyanobacterium Gloeotrichia echinulata in Lake Erken, Sweden, and its influence on the pelagic population. Mar Freshw Res 46:287-93.

Fryxell GA. 1983. Introduction. In: Fryxell GA, Ed., Survival strategies of the algae. Cambridge University Press, pp. 1-22.

Gaedke U, Kamjunke N. 2006. Structural and functional properties of low- and high-diversity planktonic food webs. J Plankton Res 28:707-18. 
Gyllström M. 2004. Induction and termination of diapause in a freshwater zooplankton community. Arch Hydrobiol 161:8197.

Gyllström M, Hansson LA. 2004. Dormancy in freshwater zooplankton: induction, termination and the importance of benthic-pelagic coupling. Aquat Sci 66:274-95.

Hairston NG Jr. 1996. Zooplankton egg banks as biotic reservoirs in changing environments. Limnol Oceanogr 41:1087-92.

Hairston NG Jr, Kearns CM. 2002. Temporal dispersal: ecological and evolutionary aspects of zooplankton egg banks and the role of sediment mixing. Integr Comp Biol 42:481-91.

Hairston NG Jr, Van Brunt RA, Kearns CM, Engstrom DR. 1995. Age and survivorship of diapausing eggs in a sediment egg bank. Ecology 76:1706-11.

Hansson LA. 1993. Factors initiating algal life-form shift from sediment to water. Oecologia 94:286-94.

Hansson LA. 1996. Algal recruitment from lake sediments in relation to grazing, sinking and dominance patterns in the phytoplankton community. Limnol Oceanogr 41:1312-23.

Hansson L-A. 2000. Synergistic effects of food chain dynamics and induced behavioral responses in aquatic ecosystems. Ecology 81:842-51.

Hansson LA, Rudstam LA, Johnson TB, Soranno P, Allen Y. 1994. Patterns in algal recruitment from sediment to water in a dimictic, eutrophic lake. Can J Fish Aquat Sci 51:2825-33.

Hillebrand H, Shurin JB. 2005. Biodiversity and aquatic food webs. In: A, B, Scharler, UM, Dunne, J, Ulanowicz, RE, Eds. Aquatic food webs-an ecosystem approach. Oxford University Press, pp. 184-97.

Holt RD, Loreau M. 2001. Biodiversity and ecosystem functioning: the role of trophic interactions and the importance of system openness. In: Kinzig AP, Pacala SW, Tilman D, Eds. The functional consequences of biodiversity: empirical progress and theoretical extensions. Princeton, NJ: Princeton University Press. p 246-62.

Jeppesen E, Jensen JP, Jensen C, Faafeng B, Hessen DO, Søndergaard M, Lauridsen TL, Brettum P, Christoffersen K. 2003. The impact of nutrient state and lake depth on topdown control in lakes: a study of 466 lakes from the temperate zone to the Arctic. Ecosystem 6:313-25.

Jones CG, Lawton JH, Shachak M. 1994. Organisms as ecosystem engineers. Oikos 69:373-86.

Kearns CM, Hairston NG Jr, Kesler DH. 1996. Particle transport by benthic invertebrates: its role in egg bank dynamics. Hydrobiologia 332:63-70.

Lewandowski J, Laskov C, Hupfer M. 2007. The relationship between Chironomus plumosus burrows and the spatial distribution of pore-water phosphate, iron and ammonium in lake sediments. Freshw Biol 52:331-43.

Marcus NH, Schmidt-Gengenbach J. 1986. Recruitment of individuals into the plankton: the importance of bioturbation. Limnol Oceanogr 31:206-10.

Matisoff G, Wang X, McCall PL. 1999. Biological redistribution of lake sediments by tubificid oligochaetes: Branchiura sowerbyi and Limnodrilus hoffmeisteri/Tubifex tubifex. J Great Lakes Res 25:205-19.
May L. 1986. Rotifer sampling-a complete species list from one visit. Hydrobiologia 134:117-20.

Meysman FJR, Middelburg JJ, Heip CHR. 2006. Bioturbation: a fresh look at Darwin's last idea. Trends Ecol Evol 21:688-95.

Naeem S, Li H. 1998. Consumer species richness and autotrophic biomass. Ecology 79:2603-15.

Petr T. 1977. Bioturbation and exchange of chemicals in the mud-water interface. In: Golterman HL, Ed. Interactions between sediments and fresh water. The Hague: Junk B. V. Publishers.

Rengefors K, Gustafsson S, Ståhl-Delbanco A. 2004. Factors regulating the recruitment of cyanobacterial and eukaryotic phytoplankton from littoral and profundal sediments. Aquat Microb Ecol 36:213-26.

Rengefors K, Karlsson I, Hansson L-A. 1998. Interactions between chemical cues from grazers and temperature in determining cyst hatching in algae. Proc R Soc B 265:1353-58.

Rodriguez P, Martinez-Madrid M, Angel J, Navarro E. 2001. Selective feeding by the aquatic oligochaete Tubifex tubifex (tubificidae, clitellata). Hydrobiologia 463:133-40.

Röndell B., Zetterberg G. 1986. Recipientkontroll vatten: metodbeskrivningar: del I: undersökningsmetoder för basprogram. Swedish Environmental Protection Agency Report 3108, Solna (in Swedish), Solna.

Scheffer M, Hosper SH, Meijer M-L, Moss B, Jeppesen E. 1993. Alternative equilibria in shallow lakes. Trends Ecol Evol 8:275-9.

Ståhl-Delbanco A, Hansson LA. 2002. Effects of bioturbation on recruitment of algal cells from the "seed bank" of lake sediments. Limnol Oceanogr 47:1836-43.

Steiner CF, Long ZT, Krumins JA, Morin PJ. 2005. Temporal stability of aquatic food webs: partitioning the effects of species diversity, species composition and enrichment. Ecol Lett 8:819-28.

Svensson J. 1998. Emission of $\mathrm{N}_{2} \mathrm{O}$, nitrification and denitrification in a eutrophic lake sediment bioturbated by Chironomus plumosus. Aquat Microb Ecol 14:289-99.

Svensson J, Leonardsson L. 1996. Effects of bioturbation by tube-dwelling chironomid larvae on oxygen uptake and denitrification in eutrophic lake sediments. Freshw Biol 35:289-300

Swedish University of Agricultural Sciences. 2007. Department of Environmental Assessment http://infol.ma.slu.se/db.html Feb 4, 2007.

Vadebonceur Y, Vander Zanden MJ, Lodge DM. 2002. Putting the lake back together: reintegrating benthic pathways into lake food web models. BioScience 52:44-53.

Vander Zanden MJ, Essington TE, Vadebonceur Y. 2005. Is pelagic top-down control in lakes augmented by benthic energy pathways? Can J Fish Aquat Sci 63:1422-31.

Viitasalo S, Katajisto T, Viitasalo M. 2007. Bioturbation changes the patterns of benthic emergence in zooplankton. Limnol Oceanogr 52:2325-39. 